\title{
Estimating regional trends of temperature in Bangladesh
}

\author{
Mst. Noorunnahar*, Md. Arafat Rahman \\ Research Student, I.S.R.T., University of Dhaka, Dhaka -1000, Bangladesh \\ Email address: \\ nnahar1@isrt.ac.bd(Mst. Noorunnahar), arahman4@isrt.ac.bd(Md. A. Rahman) \\ To cite this article: \\ Mst. Noorunnahar, Md. Arafat Rahman. Estimating Regional Trends of Temperature in Bangladesh. International Journal of \\ Environmental Monitoring and Analysis. Vol. 1, No. 5, 2013, pp. 175-181. doi: 10.11648/j.ijema.20130105.12
}

\begin{abstract}
This study aims to determine trends in the long-term monthly total data series using non-parametric methods like Mann-Kendall and Sen's T test. The change per unit time in a time series having a linear trend is estimated by applying a simple non-parametric procedure, namely Sen's estimator of slope. Serial correlation structure in the data is accounted for determining the significance level of the results of the Mann-Kendall test. The data used in this study, consists of seven divisional meteorological stations across Bangladesh. Station basis trend analysis has been performed for temperature data. For temperature data most of the stations show significant trend. There are rising rates of temperature in some months and decreasing trend in some other months obtained by these statistical tests suggesting overall significant changes in the area.
\end{abstract}

Keywords: Temperature, Mann-Kendall, Sen's T, Trend Analysis, Serial Correlation

\section{Introduction}

Various a climatic parameters such as rainfall, temperature, humidity, sunshine hour etc. of various regions of the world have shown significant trends. Global warming is mainly caused by the increase of green house gases of the atmosphere. The global average temperature increased by more than $1.3^{\circ} \mathrm{F}$ over the last century. The average temperature in the Arctic rose by almost twice as much. The buildup of greenhouse gases in our atmosphere and the warming of the planet are responsible for other changes, such as Changing precipitation patterns , Increases in ocean temperatures, sea level, and acidity, melting of glaciers and sea ice. During the 21st century, global warming is projected to continue and climate changes are likely to intensify. Scientists have used climate models to project different aspects of future climate, including temperature, precipitation, snow and ice, ocean level, and ocean acidity. Depending on future emissions of greenhouse gases and how the climate responds, average global temperatures are projected to increase worldwide by $2^{\circ} \mathrm{F}$ to $11.5^{\circ} \mathrm{F}$ by 2100 . Climate change affects our environment and natural resources, and impacts our way of life in many ways. For example: Warmer temperatures increase the frequency, intensity and duration of heat waves, which can pose health risks, particularly for young children and the elderly. Crop yield may be reduced due to shortening of the growing period because of increased temperature. Excess temperature causes heat injury, retards growth, irreparable damage to cells and cytoplasm. Besides, there are other effects of excess temperature: killing of tissues, sunburn and sun scale in leaves and fruits too. Stem growth, quality, earliness or intensity of flowering and fruit development depend on temperature rhythms.

Now it is evident from scientific study that our mother climate has undergone an abnormal human induced change. Green house gases such as carbon dioxide, methane and nitrous oxide etc. has been increased significantly over the last century. Such increased amount of green house gases act as a blanked to store infrared radiation of solar energy. Stored energy is radiated as heat and make warmer of the cooler parts of the atmosphere as well as land surface. Intergovernmental Panel on Climate Change (IPCC) has reported in their fourth assessment report that global surface temperature increased $0.74 \pm 0.18{ }^{\circ} \mathrm{C}$ during the 100 years ending in 2005 (IPCC 2007). It is also noted by IPCC (2007) that the rise of mean annual temperature will be $3.3^{\circ} \mathrm{C}$ per century. In the past, a number of studies have been carried out on trend of climate change in climatic parameters over Bangladesh. Chowdhury and Debsharma (1992) and Mia (2003) pointed out that temperature has been changed by using historical data of some selected meteorological station. Parathasarathy et al. (1987) and Divya and Mehritra (1995) reported mean annual temperature of Bangladesh has increased during the period of $1895-1980$ at $0.310 \mathrm{C}$ over the past two decades. Karmakar and Shrestha (2000) using the 1961-1990 data for Bangladesh projected that annual mean maximum 
temperature will increase to $0.40 \mathrm{C}$ and $0.730 \mathrm{C}$ by the year of 2050 and 2100 respectively. Tesemma (2010) conducted a study by using Mann-Kendal and Sen's T non-parametric test to detect significant trends in the selected years in combination with the Trend Free Pre-Whitening (TFPW) method for correcting time series data from serial correlation. In this context, it is essential to quantify changes of temperature in recent years based on the historical data. This paper presented a study conducted on the long term changes of near surface air temperature of Bangladesh using data from historic period up to recent year. Daily average temperature data of fifty to sixty years for 7 divisional stations basis on the availability of data has been collected from Bangladesh meteorological station.

\section{Methodology}

\subsection{Serial Correlation}

One of the problems in detecting and interpreting trends in hydrologic data is the confounding effect of serial dependence. Specifically, if there is a positive serial correlation (persistence) in the time series, then the nonparametric test will suggest a significant trend in a time series that is, in fact, random more often than specified by the significance level (Kulkarni and Van Storch, 1995). For this, Von Storch and Navarra (1995) suggest that the time series should be 'pre-whitened' to eliminate the effect of serial correlation before applying the Mann-Kendall test. This study incorporates this suggestion, and thus possible statistically significant trends in a precipitation observations $\left(\mathrm{x}_{1}, \mathrm{x}_{2} . . \mathrm{x}_{\mathrm{n}}\right)$ are examined using the following procedures:

1. Compute the lag-1 serial correlation coefficient (designated by $\mathrm{r}_{1}$ ).

2. If the calculated $r_{1}$ is not significant at the $5 \%$ level, then the Mann-Kendall test is applied to original values of the time series.

3. If the calculated $r_{1}$ is significant, prior to application of the Mann-Kendall test, then the 'pre-whitened' time series may be obtained as $x_{2}-r_{1} x_{1}, x_{3}-r_{1} x_{2}, \ldots, x_{n}-r_{1} x_{n-1}$.

\subsection{Mann-Kendall Test}

First of all, test for the trend in annual series was made so as to get an overall view of the possible changes in data processes. To determine If the trends found are significant, the Mann-Kendall trend test was used (Mann, 1945 and Kendall, 1948). This test is chosen over other trend detection tests based on the following factors:

(1) the Mann-Kendall test is a rank based non parametric test. When compared to parametric test like t-test the Mann-Kendall test has a higher power for non-normally distributed data which are frequently encountered in hydrological records (Onoz and Bayazit, 2003; Yue and Pilon;2004). (2) In comparison to other non-parametric tests like Spearman's rho test, the power of the MannKendall test is similar to the point where both give indistinguishable results in practice (Yue et al, 2002). (3) The Mann-Kendall test has been extensively used to determine trends in similar hydrologic studies done in the pa

$$
\mathrm{S}=\sum_{i=1}^{n-1} \sum_{j=i+1}^{n} \operatorname{sgn}\left(x_{j}-x_{i}\right)
$$

The application of trend test is done to a time series $\mathrm{xi}$ that is ranked from $i=1,2, \ldots, n-1$ and $x_{j}$, which is ranked from $j=i+1,2, . ., n$. Each of the data point $x i$ is taken as a reference point which is compared with the rest of the data points $\mathrm{X}_{\mathrm{j}}$ so that,

$$
\operatorname{sgn}\left(x_{j}-x_{i}\right)=\left\{\begin{array}{c}
+1,>\left(x_{j}-x_{i}\right) \\
0,=\left(x_{j}-x_{i}\right) \\
-1,>\left(x_{j}-x_{i}\right)
\end{array}\right.
$$

It has been documented that when $\mathrm{n} \geq 8$, the statistic $\mathrm{S}$ is approximately normally distributed with the mean. $\mathrm{E}(\mathrm{S})=0$

The test statistics $\mathrm{Zc}$ is computed as

$$
\mathrm{Z}_{\mathrm{c}}=\left\{\begin{array}{c}
\frac{\mathrm{S}-1}{\sqrt{\operatorname{Var}(\mathrm{S})}}, \mathrm{S}>0 \\
0, \mathrm{~S}=0 \\
\frac{\mathrm{S}+1}{\sqrt{\operatorname{Var}(\mathrm{S})}}, \mathrm{S}<0
\end{array}\right.
$$

Zc here follows a standard normal distribution. The variance statistic is given as

$$
\operatorname{Var}(S)=\frac{n(n-1)(2 n+5)-\sum_{t=1}^{m} t_{i}\left(t_{i}-1\right)\left(2 t_{i}+5\right)}{18}
$$

Where $t_{i}$ is considered as the number of ties up to sample i.

A positive (negative) value of $\mathrm{Z}$ signifies an upward (downward) trend. A significance level $\alpha$ is also utilized for testing either an upward or downward monotone trend (a two-tailed test). If $\mathrm{Zc}$ appears greater than $\mathrm{Z}_{\alpha / 2}$ where $\alpha$ depicts the significance level, then the trend is considered as significant.

\subsection{Sen's T Test}

This technique is an aligned rank method having procedures that first remove the block (season) effect from each datum, then sum the data over blocks, and finally produce a statistic from these sums. The aligned rank test is more powerful than its counterpart. It is distribution free and not affected by seasonal fluctuations (Sen 1968a; Van Belle and Hughes, 1984).

Test Statistic:

$$
\mathrm{T}=\left[\frac{12 m^{2}}{n(n+1) \sum_{i, j}\left(R_{i j}-R_{j}\right)^{2}}\right]^{1 / 2}\left[\sum_{i=1}^{n}\left(i-\frac{n+1}{2}\right)\left(R_{i}-\frac{n m+1}{2}\right)\right](5)
$$

The test statistic $\mathrm{T}$ follows an $\mathrm{N}(0,1)$ distribution under the null hypothesis of no trend. Positive values of $\mathrm{T}$ indicate an 'upward trend' and negative values indicate 'downward trend'. 


\subsection{Sen's Slope Estimator}

If a linear trend is present in a time series, then the true slope (change per unit time) can be estimated by using a simple non-parametric procedure developed by Sen, 1968. The magnitude of trend is predicted by the Sen's estimator.

$$
Q_{j}=\frac{x_{j}-x_{k}}{j-k} \mathrm{i}=1,2, \ldots, \mathrm{N}
$$

where $\mathrm{x}_{\mathrm{j}}$ and $\mathrm{x}_{\mathrm{k}}$ are considered as data values at time $\mathrm{j}$ and $\mathrm{k}$ $(j>k)$ correspondingly. The median of these $N$ values of $T_{i}$ is represented as Sen's estimator of slope which is given as:

$$
Q_{i}=\left\{\begin{array}{c}
Q \frac{(N+1)}{2} N \text { is odd } \\
\frac{1}{2}\left(Q_{\frac{N}{2}}+Q \frac{(N+2)}{2}\right) N \text { is even }
\end{array}\right.
$$

At the end, $\mathrm{Q}_{\text {med }}$ is computed by a two sided test at 100 $(1-\alpha) \%$ confidence interval and then a true slope can be obtained by the non-parametric test. Positive value of $\mathrm{Q}_{\mathrm{i}}$ indicates an upward or increasing trend and a negative value of $\mathrm{Q}_{\mathrm{i}}$ gives a downward or decreasing trend in the time series.

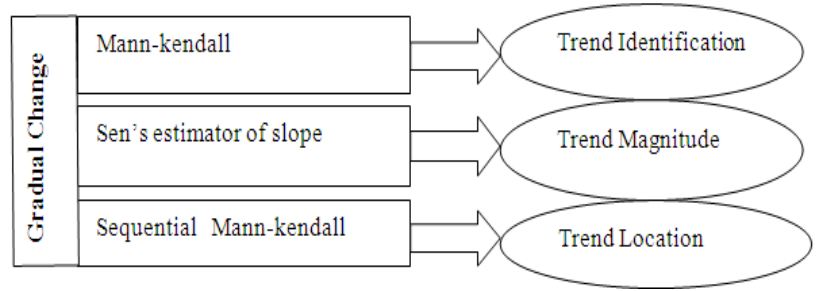

Figure 1: Trend analysis frame work

\section{Results and Discussions}

\begin{tabular}{|c|c|c|c|c|c|c|c|c|}
\hline $\begin{array}{c}\text { Available } \\
\text { period } \\
(1953-2011)\end{array}$ & Mean & $\begin{array}{c}\text { SD. } \\
\text { Deviation }\end{array}$ & $\begin{array}{c}\text { Mann- } \\
\text { kendall test } \\
\text { value } \\
\end{array}$ & $\begin{array}{c}\text { Sen's T } \\
\text { value } \\
\end{array}$ & $P$-value & Sen's slope & $\begin{array}{c}\text { Sequential } \\
\text { MK }\end{array}$ & Sequential S' \\
\hline Jan & 18.642 & 2.661 & 0.136 & 229.000 & 0.135 & 0.001 & 0.237 & 17.000 \\
\hline Feb & 21.850 & 2.401 & 0.273 & 454.000 & 0.096 & 0.029 & 0.251 & 18.000 \\
\hline Mar & 26.251 & 1.870 & 0.212 & 358.000 & 0.763 & 0.017 & 0.074 & 4.000 \\
\hline Apr & 28.363 & 1.042 & 0.116 & 196.000 & 0.202 & 0.010 & -0.111 & -8.000 \\
\hline May & 28.612 & 0.891 & 0.103 & 173.000 & 0.261 & 0.008 & -0.008 & 0.000 \\
\hline June & 28.591 & 0.711 & 0.402 & 671.000 & $0.000 * *$ & 0.022 & 0.471 & 33.000 \\
\hline July & 28.450 & 0.481 & 0.491 & 821.000 & $0.000 * *$ & 0.018 & 0.700 & 49.000 \\
\hline Aug & 28.623 & 0.542 & 0.490 & 818.000 & $0.000 * *$ & 0.020 & 0.651 & 46.000 \\
\hline Sep & 28.371 & 0.470 & 0.371 & 618.000 & $0.000 * *$ & 0.013 & 0.324 & 22.000 \\
\hline Oct & 27.111 & 0.623 & 0.442 & 738.000 & $0.000 * *$ & 0.002 & 0.500 & 35.000 \\
\hline Nov & 23.543 & 0.923 & 0.493 & 826.000 & $0.000 * *$ & 0.033 & 0.671 & 47.000 \\
\hline Dec & 19.551 & 0.861 & 0.431 & 718.000 & $0.000 * *$ & 0.027 & 0.399 & 28.000 \\
\hline
\end{tabular}

Table 1: Results of Trend Analysis for Dhaka Station

From the above table 1 we can conclude that most of the months of Dhaka Station show significant trend except January, February, March, April and May show insignificant trend at 5\% level of significance. According to
Mann-Kendall test and Sen's T test all months show upward trend. The slope estimates show positive rates of change for these months also.

\begin{tabular}{|c|c|c|c|c|c|c|c|c|}
\hline $\begin{array}{c}\text { Available } \\
\text { period } \\
(\mathbf{1 9 4 8 - 2 0 1 1 )}\end{array}$ & Mean & $\begin{array}{c}\text { SD. } \\
\text { Deviation }\end{array}$ & $\begin{array}{c}\text { Mann- } \\
\text { kendall test } \\
\text { value } \\
\end{array}$ & Sen's T value & $P$-value & Sen's slope & $\begin{array}{c}\text { Sequential } \\
\text { MK }\end{array}$ & Sequential $\mathbf{S}$ \\
\hline Jan & 19.691 & 0.684 & 0.022 & 35.000 & 0.819 & 0 & -0.149 & -11.000 \\
\hline Feb & 22.064 & 0.756 & 0.165 & 268.000 & 0.073 & 0.012 & 0.250 & 18.000 \\
\hline Mar & 25.590 & 0.717 & 0.143 & 233.000 & 0.119 & 0.010 & -0.083 & -6.000 \\
\hline Apr & 27.813 & 0.815 & 0.066 & 108.000 & 0.472 & 0.005 & -0.136 & -10.000 \\
\hline May & 28.634 & 0.646 & -0.049 & -80.000 & 0.595 & -0.003 & -0.010 & -1.000 \\
\hline June & 28.053 & 0.634 & 0.220 & 353.000 & $0.018 * *$ & 0.011 & 0.172 & 12.000 \\
\hline July & 27.687 & 0.500 & 0.343 & 549.000 & $0.000 * *$ & 0.012 & 0.293 & 21.000 \\
\hline Aug & 27.848 & 1.054 & 0.320 & 517.000 & $0.001 * *$ & 0.016 & 0.273 & 19.000 \\
\hline Sep & 28.004 & 0.445 & 0.281 & 450.000 & $0.002 * *$ & 0.011 & 0.251 & 17.000 \\
\hline Oct & 27.405 & 0.564 & 0.317 & 510.000 & $0.001 * *$ & 0.015 & 0.212 & 15.000 \\
\hline Nov & 24.442 & 0.957 & 0.358 & 583.000 & $0.000 * *$ & 0.029 & 0.425 & 30.000 \\
\hline Dec & 20.708 & 0.865 & 0.296 & 479.000 & $0.001 * *$ & 0.021 & 0.104 & 7.000 \\
\hline
\end{tabular}

Table 2: Results of Trend Analysis for Chittagong Station 
From the above table 2 we can conclude that most of the months of Chittagong Station show significant trend except January, February, March, April and May show insignificant trend at $5 \%$ level of significance. According to
Mann-Kendall test and Sen's T test all months show upward trend. The slope estimates show positive rates of change for these months also.

Table 3: Result of Trend Analysis of Rajshahi Station

\begin{tabular}{|c|c|c|c|c|c|c|c|c|}
\hline $\begin{array}{c}\text { Available } \\
\text { period } \\
\text { (1964-2011) }\end{array}$ & Mean & $\begin{array}{c}\text { SD. } \\
\text { Deviation }\end{array}$ & $\begin{array}{c}\text { Mann- } \\
\text { kendall test } \\
\text { value }\end{array}$ & $\begin{array}{l}\text { Sen's T } \\
\text { value }\end{array}$ & $P$-value & Sen's slope & $\begin{array}{c}\text { Sequential } \\
\text { MK }\end{array}$ & $\begin{array}{c}\text { Sequential } \\
\mathrm{S}^{\prime}\end{array}$ \\
\hline Jan & 16.948 & 1.168 & -0.394 & -440.000 & $0.000 * *$ & -0.05 & -0.521 & -37.000 \\
\hline Feb & 20.138 & 1.132 & -0.072 & -80.000 & 0.482 & -0.008 & -0.090 & -6.000 \\
\hline Mar & 25.276 & 1.280 & -0.026 & -29.000 & 0.803 & -0.004 & -0.111 & -8.000 \\
\hline Apr & 29.151 & 1.388 & -0.146 & -163.000 & 0.149 & -0.017 & -0.354 & -25.000 \\
\hline May & 29.456 & 1.404 & -0.110 & -123.000 & 0.278 & -0.016 & -0.186 & -14.000 \\
\hline June & 29.219 & 0.792 & 0.064 & 71.000 & 0.533 & 0.005 & -0.046 & -3.000 \\
\hline July & 28.615 & 0.508 & 0.289 & 318.000 & $0.005 * *$ & 0.016 & 0.352 & 24.000 \\
\hline Aug & 28.740 & 0.435 & 0.393 & 429.000 & $0.000 * *$ & 0.018 & 0.602 & 42.000 \\
\hline Sep & 28.402 & 0.452 & 0.046 & 50.000 & 0.662 & 0 & 0.104 & 7.000 \\
\hline Oct & 26.771 & 0.696 & -0.139 & -153.000 & 0.175 & -0.009 & -0.139 & -10.000 \\
\hline Nov & 22.738 & 0.899 & -0.113 & -125.000 & 0.270 & -0.01 & -0.056 & -4.000 \\
\hline Dec & 18.340 & 0.905 & -0.108 & -120.000 & 0.289 & -0.009 & -0.061 & -4.000 \\
\hline
\end{tabular}

From the above table 3 we can conclude that three months (January, July and August) of Rajshahi Station show significant trend and remaining months show insignificant trend at 5\% level of significance. According to
Mann-Kendall test and Sen's T test June, July, August and September show upward trend. The slope estimates show positive rates of change for these months also. Only one month (September) indicates no trend.

Table 4: Results of Trend Analysis for Khulna Station

\begin{tabular}{|c|c|c|c|c|c|c|c|c|}
\hline $\begin{array}{c}\text { Available } \\
\text { period } \\
(\mathbf{1 9 4 8 - 2 0 1 1 )}\end{array}$ & Mean & $\begin{array}{c}\text { SD. } \\
\text { Deviation }\end{array}$ & $\begin{array}{c}\text { Mann-kendall } \\
\text { test value }\end{array}$ & Sen's $T$ value & $P$-value & $\begin{array}{l}\text { Sen's } \\
\text { slope }\end{array}$ & $\begin{array}{c}\text { Sequential } \\
\text { MK }\end{array}$ & Sequential S' \\
\hline Jan & 18.578 & 1.093 & -0.192 & -347.00 & $0.031 * *$ & -0.017 & -0.194 & -23.00 \\
\hline Feb & 21.900 & 1.092 & 0.090 & 163.00 & 0.313 & 0.009 & 0.135 & 16.00 \\
\hline Mar & 26.495 & 1.186 & 0.098 & 178.00 & 0.270 & 0.009 & 0.079 & 9.00 \\
\hline Apr & 29.314 & 1.178 & -0.070 & -125.00 & 0.439 & -0.004 & -0.055 & -7.00 \\
\hline May & 29.874 & 0.975 & -0.072 & -130.00 & 0.421 & -0.005 & -0.182 & -21.00 \\
\hline June & 29.254 & 0.657 & 0.119 & 214.00 & 0.184 & 0.006 & 0.147 & 17.00 \\
\hline July & 28.448 & 0.599 & 0.458 & 821.00 & $0.000 * *$ & 0.019 & 0.585 & 68.00 \\
\hline Aug & 28.557 & 0.509 & 0.490 & 871.00 & $0.000 * *$ & 0.019 & 0.593 & 70.00 \\
\hline Sep & 28.432 & 0.496 & 0.370 & 656.00 & $0.000 * *$ & 0.013 & 0.482 & 56.00 \\
\hline Oct & 27.319 & 1.212 & 0.199 & 356.00 & $0.027 * *$ & 0.011 & 0.193 & 23.00 \\
\hline Nov & 23.892 & 1.112 & 0.283 & 511.00 & $0.001 * *$ & 0.023 & 0.325 & 39.00 \\
\hline Dec & 19.738 & 1.005 & 0.031 & 56.00 & 0.732 & 0.002 & 0.019 & 2.00 \\
\hline
\end{tabular}

From the above table 4 we can conclude that six months (January, July, August, September, October, November) of Khulna Station show significant trend. According to MannKendall test and Sen's T test almost all months show upward trend except January, April and May. The slope estimates show positive rates of change for these months also. 
Table 5: Results of Trend Analysis of Barishal Station

\begin{tabular}{ccccccccc}
\hline $\begin{array}{c}\text { Available } \\
\text { period } \\
\text { (1949-2011) }\end{array}$ & Mean & SD. Deviation & $\begin{array}{c}\text { Mann- } \\
\text { kendall test } \\
\text { value }\end{array}$ & Sen's T value & P -value & Sen's slope & Sequential MK & $\begin{array}{c}\text { Sequential } \\
\text { S' }\end{array}$ \\
\hline Jan & 18.682 & 2.761 & -0.351 & -625.000 & $0.002 * *$ & -0.031 & -0.380 & -45.000 \\
Feb & 21.562 & 1.123 & -0.009 & -17.000 & 0.921 & 0 & 0.105 & 11.000 \\
Mar & 25.981 & 1.101 & -0.054 & -82.000 & 0.614 & -0.003 & -0.004 & -1.000 \\
Apr & 28.431 & 1.011 & -0.091 & -156.000 & 0.334 & -0.007 & 0.032 & 4.000 \\
May & 29.122 & 0.791 & -0.182 & -315.000 & 0.050 & 0.013 & -0.271 & -32.000 \\
June & 28.631 & 0.642 & -0.012 & -21.000 & 0.901 & 0 & 0.047 & 18.000 \\
July & 27.911 & 0.464 & 0.123 & 214.000 & 0.183 & 0.004 & 0.166 & 2.000 \\
Aug & 28.192 & 0.471 & 0.185 & 328.000 & $0.040 * *$ & 0.006 & 0.204 & 24.000 \\
Sep & 28.213 & 0.480 & -0.101 & -180.000 & 0.264 & -0.003 & -0.136 & -16.000 \\
Oct & 27.600 & 0.428 & 0.026 & 2.000 & 0.951 & 0.006 & 0.333 & 2.000 \\
Nov & 23.661 & 0.936 & 0.067 & 120.000 & 0.458 & 0.005 & 0.108 & 13.000 \\
Dec & 19.511 & 0.999 & -0.201 & -361.000 & $0.025 * *$ & -0.051 & -0.14 & -17.000 \\
\hline
\end{tabular}

From the above table 5, we can conclude that according to Mann-Kendall test and Sen's T test most of the months of Barishal Station show decreasing trend. But January,
August and December show significant trend at 5\% level of significance. The slope estimates show positive rates of change for some months

Table 6: Results of Trend Analysis of Sylhet Station

\begin{tabular}{|c|c|c|c|c|c|c|c|c|}
\hline $\begin{array}{c}\text { Available } \\
\text { period } \\
(1956-2011)\end{array}$ & Mean & SD. Deviation & $\begin{array}{l}\text { Mann- } \\
\text { kendall test } \\
\text { value }\end{array}$ & $\begin{array}{c}\text { Sen's T } \\
\text { value }\end{array}$ & $P$-value & Sen's slope & Sequential MK & Sequential S' \\
\hline Jan & 18.159 & 1.375 & 0.139 & 204.000 & 0.140 & 0.01 & 0.262 & 56.000 \\
\hline Feb & 20.678 & 2.584 & 0.168 & 247.000 & 0.074 & 0.021 & 0.216 & 46.000 \\
\hline Mar & 24.133 & 0.968 & 0.043 & 63.000 & 0.652 & 0.004 & -0.020 & -4.000 \\
\hline Apr & 25.888 & 1.051 & 0.018 & 26.000 & 0.856 & 0 & -0.005 & -1.000 \\
\hline May & 26.686 & 0.996 & 0.128 & 188.000 & 0.174 & 0.012 & 0.108 & 23.000 \\
\hline June & 27.230 & 0.623 & 0.256 & 382.000 & $0.005 * *$ & 0.015 & 0.184 & 39.000 \\
\hline July & 27.627 & 0.583 & 0.196 & 286.000 & $0.038 * *$ & 0.012 & 0.206 & 44.000 \\
\hline Aug & 27.885 & 0.597 & 0.293 & 426.000 & $0.002 * *$ & 0.016 & 0.291 & 62.000 \\
\hline Sep & 27.502 & 0.634 & 0.234 & 341.000 & $0.013 * *$ & 0.015 & 0.211 & 44.000 \\
\hline Oct & 26.167 & 0.713 & 0.384 & 561.000 & $0.000 * *$ & 0.026 & 0.429 & 92.000 \\
\hline Nov & 33.185 & 2.149 & 0.325 & 475.000 & $0.001 * *$ & 0.025 & 0.367 & 78.000 \\
\hline Dec & 19.316 & 0.778 & 0.398 & 582.000 & $0.000 * *$ & 0.026 & & \\
\hline
\end{tabular}

From the above table 6 , we can conclude that most of the months of Sylhet Station show significant trend except January, February, March, April and May show insignificant trend at 5\% level of significance. According to
Mann-Kendall test and Sen's T test all months show upward trend. The slope estimates show positive rates of change for these months also. 
Table 7: Results of Trend Analysis of Rangpur Station

\begin{tabular}{llccccccc}
\hline $\begin{array}{c}\text { Available } \\
\begin{array}{c}\text { priod (1954- } \\
\text { 2011) }\end{array}\end{array}$ & Mean & SD. Deviation & $\begin{array}{c}\text { Mann- } \\
\text { kendall } \\
\text { test value }\end{array}$ & $\begin{array}{c}\text { Sen's T } \\
\text { value }\end{array}$ & P-value & Sen's slope & $\begin{array}{c}\text { Sequential } \\
\text { MK }\end{array}$ & Sequential S' \\
\hline Jan & 16.600 & 3.182 & 0.043 & 65.00 & 0.651 & 0.003 & -0.010 & -1.00 \\
Feb & 19.224 & 2.846 & 0.296 & 451.00 & $0.001^{* *}$ & 0.033 & 0.261 & 18.00 \\
Mar & 23.555 & 2.490 & 0.218 & 332.00 & $0.019 * *$ & 0.031 & 0.194 & 14.00 \\
Apr & 26.419 & 2.607 & -0.095 & -146.00 & 0.305 & -0.017 & -0.083 & -6.00 \\
May & 27.169 & 2.224 & 0.106 & 161.00 & 0.257 & 0.012 & 0.189 & 14.00 \\
June & 28.258 & 2.307 & 0.155 & 234.00 & 0.099 & 0.009 & 0.212 & 15.00 \\
July & 28.220 & 1.950 & 0.270 & 408.00 & $0.004^{* *}$ & 0.020 & 0.296 & 21.00 \\
Aug & 28.524 & 1.871 & 0.251 & 390.00 & $0.007 * *$ & 0.014 & 0.344 & 24.00 \\
Sep & 27.861 & 1.843 & 0.175 & 265.00 & 0.062 & 0.013 & 0.020 & 2.00 \\
Oct & 26.392 & 2.480 & 0.118 & 179.00 & 0.207 & 0.008 & 0.091 & 7.00 \\
Nov & 22.295 & 2.329 & 0.337 & 510.00 & $0.000^{* *}$ & 0.029 & 0.548 & \\
Dec & 18.449 & 2.853 & 0.178 & 271.00 & 0.056 & 0.017 & 0.250 & 39.00 \\
\hline
\end{tabular}

From the above table 7, we can conclude that five months (February, March, July, August, and November) of Rangpur Station show significant trend and remaining months (January, April, May, June, September, October, and December) show insignificant trend at 5\% level of significance. According to Mann-Kendall test and Sen's T test almost all months show upward trend except April. The slope estimates show positive rates of change for these months also.

\section{Conclusion}

In present study, we analyze the temperature data for more than 50 years based on their data availability for divisional city like Dhaka, Barishal, Chittagong, Khulna, Rajshahi, Sylhet and Rangpur. That means depends on the result in terms of geographical location we can conclude the overall comments for hydro-meteorological scenario in Bangladesh. We know that Bangladesh is Agri-based country, so most of the people maintain their income depends on agricultural activities. However, each and every activities of agriculture highly correlated with weather component like temperature and rainfall. In this study we try to find out pattern or trend of temperature in 7 divisional cities. The Zc value of MK Test represents both positive and negative trend in the area. Sen's Slope is also indicating increasing and decreasing magnitude of slope in correspondence with the Mann-Kendall Test values. Majority of the months of the stations show upward trend along with some significant values. Some of the months show no trend by the value of the slope estimator. Further, study of the area may reveal other aspects which will be helpful in controlling flood, global warming and taking necessary action for agriculture activities in this particular area.

\section{References}

[1] Ashoke Basistha, DS Arya, and NK Goel, 2009. Analysis of historical changes in rainfall in the indian himalayas. International Journal of Climatology, 29(4), 555-572.

[2] B Bonaccorso, A Cancelliere, G Rossi, 2005. Detecting trends of extreme rainfall series in sicily, 2, 7-11.

[3] Bihrat Onoz and Mehmetcik Bayazit, 2003. The power of statistical tests for trend detection. Turkish Journal of Engineering and Environmental Sciences, 27(4), 247-251.

[4] Donald H Burn, Omar I Abdul Aziz, and Alain Pietroniro, 2004. A comparison of trends in hydrological variables for two watersheds in the mackenzie river basin, Canadian Water Resources Journal, 29(4), 283-298.

[5] Donald H Burn and Mohamed A Hag Elnur, 2002. Detection of hydrologic trends and variability. Journal of hydrology, 255(1), 107-122.

[6] Ercan Kahya and Serdar Kalayc, 2004. Trend analysis of stream ow in turkey. Journal of Hydrology, 289(1), 128-144.

[7] Harry F Lins and James R Slack, 1999. Streamow trends in the united states, Geophysical research letters, 26(2), 227230.

[8] Mikdat Kadioglu, 1997. Trends in surface air temperature data over turkey. International Journal of Climatology, 17(5),511-520.

[9] M Bani-Domi, 2005. Trend analysis of temperatures and precipitation in jordan. Dept. of Geography Yarmouk University, Irbid-Jordan

[10] Pranab Kumar Sen, 1968. Estimates of the regression coe cient based on kendall's tau. Journal of the American Statistical Association, 63(324), 1379-1389.

[11] Pranab Kumar Sen, 1968. On a class of aligned rank order 
tests in two-way layouts, The Annals of Mathematical Statistics, pages 1115-1124.

[12] Qiang Zhang, Chunling Liu, Chong-yu Xu, Youpeng Xu, and Tong Jiang, 2006. Observed trends of annual maximum water level and stream ow during past 130 years in the yangtze river basin, china. Journal of hydrology, 324(1), 255-265.

[13] Robert M Hirsch, James R Slack, and Richard A Smith, 1982. Techniques of trend analysis for monthly water quality data. Water resources research, 18(1),107-121.

[14] Shamsuddin Shahid, 2010. Rainfall variability and the trends of wet and dry periods in Bangladesh. International Journal of Climatology, 30(15), 2299-2313.

[15] Shabtai Cohen and Gerald Stanhill, 1996. Contemporary climate change in the jordan valley. Journal of applied Meteorology, 35(7), 1051-1058.

[16] Sheng Yue, Paul Pilon, Bob Phinney, and George Cavadias, 2002. The inuence of autocorrelation on the ability to detect trend in hydrological series. Hydrological Processes, 16(9), 1807-1829.

[17] Turgay Partal and Ercan Kahya, 2006. Trend analysis in turkish precipitation data. Hydrological Processes, 20(9), 2011-2026.

[18] Vijay Kumar, Sharad K Jain, and Yatveer Singh, 2010. Analysis of long-term rainfall trends in india. Hydrological Sciences Journal-Journal des Sciences Hydrologiques, 55(4), 484-496

[19] Von Storch, H., 1995. Misuses of statistical analysis in climate research, in Analysis of Climate Variability: Applications of Statistical Techniques, edited by H. V. Storch and A. Navarra, pp. 11-26, Springer-Verlag, New York.

[20] Yun-Sheng Yu, Shimin Zou, and Donald Whittemore (1993). Non-parametric trend analysis of water quality data of rivers in kansas. Journal of Hydrology, 150(1), 61-80.

[21] Zelalem K Tesemma, Yasir A Mohamed, and Tammo S Steenhuis, 2010. Trends in rainfall and runo in the blue nile basin, Hydrological Processes, 24(25), 3747-3758.

[22] Intergovernmental Panel on Climate Change (IPCC), http://www.ipcc.ch/

[23] United States Environmental Protection Agency, http://www.epa.gov/ 